\title{
A Study on Women EntrepreneurshipIn Guntur District of Andhra Pradesh
}

\author{
${ }^{1}$ Shakunthala Devi Jakkula, ${ }^{2}$ Dr.K.Dhana Lakshmi, \\ Research Scholar,Dept.of Sociology and Social Work, AcharyaNagarjunaUniversity, Guntur-522 $510 .$. \\ Asst.Professor, Dept.of Sociology and Social Work, AcharyaNagarjuna University, Guntur-522 510.
}

\begin{abstract}
Entrepreneurship is an essential forerunning factor for national development. Nurturing an individual's natural spirit of entrepreneurship is a powerful key to economic development, which takes its major share in the developing countries. Small and medium enterprises provide enormous employment opportunities to people. Moreover, small enterprise is frequently involved as a key player in the process of local economic development and the re-organisation of national economies. "Women Entrepreneur" is a person who accepts challenging role to meet her personal needs and become economically independent. The state of Andhra Pradesh is the industrially developed area in which some of the entrepreneurs excel in small scale industry. Even though the government organizes women by various associations, they are not ready to undertake the business. As compared to men, women are less motivated to start business units due to some unwanted fear, lack of motivation and kind of activities. The study aims at undertaking the entrepreneurial development among women and highlights their motivational forces and relationship between socio-economic background of women entrepreneurs' factors and their existing entrepreneurial trains.
\end{abstract}

\section{INTRODUCTION}

Entrepreneurship is an essential forerunning factor for national development. Nurturing an individual's natural spirit of entrepreneurship is a powerful key to economic development, which takes its major share in the developing countries. Small and medium enterprises provide enormous employment opportunities to people. Moreover, small enterprise is frequently involved as a key player in the process of local economic development and the reorganisation of national economies. The origin of women entrepreneurship in India geared up only in last three decades. History has full of evidences of individual entrepreneur whose creativity has led to the industrialization of many nations. The spirit of enterprising transforms ordinary men into entrepreneurs and ideas into economic realities.

Entrepreneurship is the ability to perceive an opportunity, the foresight to see scope for its exploration, the courage to undertake the initiative and trying to take risks. According to Mclelland, "Entrepreneurship is the purposeful activity of an individual or a group of associated individuals, undertaken to initiate, maintain or accredit profit by production or distribution of economic goods and services". An entrepreneur is an individual who carries out actions that result in innovations or introduction of new products or introduction of existing product in the new market and is responsible for risks and has a high degree of achievement and motivation. Also capable of organizing resources to overcome challenging ventures out of which she/he derives high level of satisfaction. Entrepreneurship may be regarded as a powerful tool for economic development of a predominantly agricultural country like India. Since independence, small-scale entrepreneurship programme has contributed significantly to the economic growth. Entrepreneurship refers to the skill of organizing new economic enterprises, managing them, in valuing risks. The Indian society has not bothered to pay due attention to appreciate and involve its women members in the promotion of its economic development. When both men and women together work and contribute for the economic development, no doubt that the national economy will develop at a faster rate.

\section{NEED FOR WOMEN ENTREPRENEURSHIP}

When women move forward the family as a whole moves, the village moves and the nation moves. These words of Pandit Jawaharlal Nehru are often repeated because this is an accepted fact. Employment gives economic status to women which in turn pave the way for social status. Gone are the days, when a man could boast of being capable of feeding the whole family. But now the scenario is changing fast with modernization, urbanisation and development of education and business. Women are now seeking gainful employment in several fields in increasing numbers with the spread of education and new awareness women entrepreneurs are 
spreading their wings to higher levels. Entrepreneurship for women can be planned and developed and the need for providing appropriate awareness and environment to promote entrepreneurship is of vital importance.

\section{REVIEW OF LITERATURE}

P.Venkateswarlu and P.S.Ravindra (2015) studied on rural entrepreneurs which play a vital role in the overall economic development of the country. The growth and development of rural entrepreneurship facilitate self employment which results in wider dispersal of economic and industrial activities and helps in the maximum utilization of locally available raw materials and labour. It is fact that the majority of rural entrepreneurs are facing several problems due to the lack of basic amenities in rural areas like, lack of education, financial problems, marketing hurdles, Management and human resource problems, insufficient technical and conceptual ability etc. Keeping the above facts, an attempt was made to study the technological, institutional and financial problems and prospects of rural entrepreneurs with special reference to Visakhapatnam district.

Dharmendra Kumar (2014) analyzed the influence of socio cultural factors on women entrepreneurs of Uttarakhand State with the specific aim to identify socio -cultural factors and women entrepreneurs' perception towards those, to find out the impact of socio - cultural status and locale on women entrepreneurs and to examine the effect of socio - cultural factors on women entrepreneurs. Through the research found that entrepreneur's socio - cultural status, their residential background has a played a significant impact on the opinion, views and behaviour of women entrepreneurs, research also concluded that socio - cultural factors significantly affect the women entrepreneurs and their contribution towards state economy. Many of the sociocultural factors are identified which are highly influential on entrepreneurship.

Vijay Kumbhar (2013) discusses the issues regarding women entrepreneurship in rural India. The major Findings of this study reveal that absence of definite agenda of life, absence of balance between family and career obligations of women, poor degree of financial freedom of women, absence of direct ownership of the property, the paradox of entrepreneurial skill \& finance in economically rich and poor women, no awareness about capacities, low ability to bear risk, problems of work with male workers, negligence by financial institutions, lack of self -confidence, lack of professional education, mobility constraints and lack of interaction with successful entrepreneurs are major problems of women entrepreneurship development in India.

A.B. Siddiqui (2012) investigates the problems and challenges faced by women entrepreneurs in India .Women Entrepreneur is a person who accept $\mathrm{s}$ challenging role to meet her personal needs and become economically independent. Many women have this quality but they never got a platform to showcase their talents and hence they don't know their real abilities. Some of the major problems identified are women's family obligations, Gender inequality, Problem of Finance, Low - level risk taking attitude, and the male - female competition. It concludes that the problems of women entrepreneurs can be eradicated by appropriate training, incentives, encouragement and motivation, social recognition of their entrepreneurial abilities, and family's moral support.

\section{OBJECTIVES OF THE STUDY}

The present study has been carried out with the following objectives:

1. To study the socio-economic Profile of the rural women entrepreneurs in Guntur District of Andhra Pradesh.

2. To correlate the socio-economic factors with entrepreneurial aspects of rural women entrepreneurship.

3. To offer suggestions for developing the rural women entrepreneurial activities.

\section{RESEARCH METHODOLOGY}

Rural Women entrepreneurs who are the main source of primary data are collected from the women entrepreneurs through a scheduled method. As the area of study is limited to Guntur District and as the total women population is numerable, the researcher finally 120 respondents were selected through selective random sampling technique and included in the study from various sub-divisions of Guntur District who have engaged to start an enterprise and running successfully. Personal interview is the major tool of data collection Interview technique is to be made at rural women entrepreneurs. The secondary data are also proposed to collect from various books, journals and departments.

\section{SCOPE OF THE STUDY}

The study focuses on the rural women entrepreneurs in Guntur District of Andhra Pradesh. The selected district with its good infrastructural facility, offers sound prospects for industrial developments. The scope of the study encompasses rural women entrepreneurs in Guntur District and the problems faced by rural women entrepreneurs who are engaged in entrepreneurial activities. The study is limited only to the rural women entrepreneurs of selected groups in Guntur District. 


\section{SUMMARY OF FINDINGS}

1. Majority of the women entrepreneurs are married and got settled in life in which 37.3 per cent belongs to the age group of 31-40 and 36 per cent belong to the age group of 21-30.

2. Education wise analysis reveals that 58 per cent of women entrepreneurs are educated and 42 per cent are uneducated. 92 per cent of the women are degree holders; the availability of distance education is fostering them to acquire degree. It has been found that graduate women entrepreneurs are as high as 30.7 per cent that reveals the entrance of graduate entrepreneurs into entrepreneurship. In the wake of growing importance to the education and with the advent of open universities a very high per cent of women entrepreneurs are able to graduate. Both below SSC and uneducated women entrepreneurs consist 27.3 per cent.

3. Among the women entrepreneurs covered by the sample study 28.7 per cent are from OC community and 45.3 are from BC community, it is found out that only 26 per cent are from SC and ST community.

4. The study reveals that majority of women entrepreneurs i.e. 83.3 per cent are married and 10.3 per cent are unmarried, it has been spotted that there are 6.3 per cent widowed women entrepreneurs. Married women entrepreneurs play a dominant role as they adequately receive support from their family members especially from their husbands.

5. The study reveals that 62 per cent of women entrepreneurs are from nuclear family and 38 per cent are from joint family. One of the main findings of the study is that family background and family cooperation of the entrepreneurs have a significant bearing on the orientation of entrepreneurial activity and help them in setting up an enterprise.

6. All the women entrepreneurs taken for the study have got sufficient support and cooperation from their family members whether they belong to the independent or joint family.

7. It has been discovered from the study that 90.7 of women entrepreneurs are fortunate to avail cooperation from family.

8. It is interesting to note that their husbands motivated 57 per cent of entrepreneurs, 7.3 per cent were self motivated. But the rest were motivated by their relatives and friends.

9. It is also found that for 52 per cent of the women entrepreneurs family formulated that the project to set up enterprise. Only for 8 per cent of the total sample, assistance is obtained from agencies that explain the trivial role played by agencies in this regard.

10. Another notable finding from the study, when employee's perspective is taken into consideration, women entrepreneurs have evinced satisfactory skills in recruiting, paying salaries, managing employees etc. because employees who are working under women entrepreneurs are reaching targets beforehand based on the instructions provided and the women entrepreneurs are also satisfied with the performance of their employees.

11. The study reveals that 56.7 per cent of women entrepreneurs are house wives turned women entrepreneurs and it is found for 41.7 per cent of respondents turned women entrepreneurs based on the advice or influence of family members or friends.

12. It is a propitious omen to find out that the demand for the products of women entrepreneurs is 37 per cent good, 28.7, per cent excellent and 21.7 per cent satisfactory as evinced by the respondents.

13. The study reveals that 44.7 per cent of women entrepreneurs are following market price pricing strategy, 26.3 per cent are following cost plus pricing strategy and 24.7 per cent are following different methods. Majority of the respondents i.e. 61 per cent chose the pricing strategy for profit maximization and 20.7 per cent followed it for improvement of market share.

\section{SUGGESTIONS}

1. It is suggested that women entrepreneurs should acquire basic qualification which engenders to acquaint themselves with fundamentals relating to business techniques to run the business smoothly.

2. Proper uplifting measures should be adopted by government for SC and ST women to set up enterprises because they comprise of only 26 per cent from the sample study.

3. It is suggested that women entrepreneurs should be properly trained in terms of business strategies and skills to fare good in business activities like adopting appropriate pricing strategy, promotional activity, assessment of consumers buying factors, marketing etc.

4. Marketing and promotional activates is another area in which women entrepreneurs are highly dependent on others in their business, with proper business training this dependency can be obliterated. With proper training and development, individual accomplishment can be enabled among women entrepreneurs.

5. Regarding the problems faced by women entrepreneurs, based on the study they have to be properly equipped with fair debt collection methods from long time pending customers, winning strategies in fierce competition, financial closure techniques, labour management skills etc. 
6. It is suggested that on a large scale basis, training and usage techniques to implement accounting packages should be given for the benefit of all the women entrepreneurs.

7. As majority of women entrepreneurs are not in any association, they should be encouraged to be a part of women entrepreneurship association to solve the problem they face as entrepreneurs as a strong association.

\section{REFERENCES}

[1] Mclelland, D.C., “The Achieving Society”, D.VanNorstrand Co. Inc, New York, 1961, p.8.

[2] Lalitha, Rani D., Women Entrepreneurs for Small Business Creation Lessons from Experience, Oxford and IBH, New Delhi, 1991, pp.35-36.

[3] Bisht, Narendra.S and Sarma, Pamela K., "Entrepreneurship, Relfection and Investigation, Chugh Publication, Allahabad, 1989, p.21.

[4] Dr.P.Venkateswarlu and Dr.P.S.Ravindra, "An Empirical Study on Problem and Prospects of Rural Entrepreneurs with Special Reference to Visakhapatnam District”, International Journal of Management and Commerce Innovations, Vol - 2, Issue - 2, pp: 458 - 467, March 2015.

[5] Dharmendra Kumar, "Socio - Cultural Influence on Women Entrepreneurs: A Study of Uttarakhand State", International Journal of Trade and Commerce, Volume 3, No. 1, June, 2014.

[6] Vijay Kumbhar, "Some Critical Issues of Women Entrepreneurship in Rural India" European Academic Research, vol - I, issue - 2, May, 2013.

[7] A.B. Siddiqui, "Problems Encountered by Women Entrepreneurs in India", InternationalJournal of Applied Research \& Studies, Vol- I, Issue - 1, Nov, 2012. 